\title{
PERJUMPAAN INJIL DAN TRADISI JAWA TIMURAN DALAM PELAYANAN MISI KONTEKSTUAL
}

\author{
Krido Siswanto \\ Sekolah Tinggi Teologi Simpson Ungaran \\ Jl. Agung No. 66, Krajan, Kel. Susukan, Kec. Ungaran Timur, Kab. Semarang \\ Email: kridosiswanto@sttsimpson.ac.id
}

\begin{abstract}
Krido Siswanto, Encounter Evangelist and Easterlies Tradition in Contextual Mission Service. A contextual service is one Method of mission that is being developed by many churches in this time. In many areas these services are developed, including congregation of GKII Pulerejo Madiun. Certainly in the service of mission need a principles the firm of Christian faith. This contextual services which will proclaim the evangelist whose existence is in the midst of society with a tradition of Java easterlies. The writer will describe about method of this service contextual where is an encounter between evangelist with traditions of easterlies which was embraced by the peoples in Pulerejo Madiun East Java.
\end{abstract}

Keyword: tradition of Java, encounter evangelist, contextual mission

\begin{abstract}
ABSTRAK: Krido Siswanto, Perjumpaan Injil dan Tradisi Jawa Timuran Dalam Pelayanan Misi Kontekstual. Pelayanan Kontekstual merupakan salah satu model pelayanan misi yang sedang dikembangkan oleh banyak gereja masa kini. Di berbagai daerah pelayanan ini dikembangkan, diantaranya adalah di GKII jemaat Pulerejo Madiun. Tentunya dalam pelayanan misi tersebut membutuhkan suatu prinsipprinsip iman Kristen yang teguh. Yang mana pelayanan kontekstual ini akan memberitakan Injil yang keberadaannya ada di tengah-tengah masyarakat yang memiliki tradisi Jawa Timuran. Penulis akan menguraikan model pelayanan kontekstual ini dimana ada perjumpaan antara Injil dengan tradisi-tradisi Jawa Timuran yang masih dianut oleh masyarakat Desa Pulerejo kabupaten Madiun Jawa Timur.
\end{abstract}

Kata Kunci: Tradisi Jawa, Perjumpaan Injil, Misi Kontekstual

\section{PENDAHULUAN}

Gereja Kemah Injil Indonesia (GKII) Jemaat Pulerejo berada di Desa Pulerejo dan dirintis mulai tahun 1980. Setiap orang yang bertobat oleh para penginjilnya diharuskan meninggalkan tradisi-tradisi yang ada dalam masyarakat Jawa Timuran. Sehingga dalam perkembangannya terkesan orang Kristen ini menjadi eksklusif. Pada saat ada upacara tradisi Jawa Timuran yang diselenggarakan oleh masyarakat orang Kristen sudah tidak kelihatan lagi. Akan tetapi pada saat penulis ditempatkan di GKII Jemaat Pulerejo ini sekitar tahun 1997-an, penulis dalam pelayanannya menggunakan model kontekstual. Penulis sedikit mendapat kecaman baik dari kalangan gereja sendiri maupun dari denominasi lain. Ada asumsi bahwa penulis menghidupkan tradisi-tradisi yang sudah ditinggalkan oleh orang-orang Kristen. Padahal yang diterapkan adalah proses kontekstualisasi dimana Injil atau teologi dikembangkan dan diterap- kan dalam budaya setempat. ${ }^{1}$ Untuk itu kontekstualisasi Injil dalam budaya dan penerapannya dalam pelayan Kristen perlu dikaji dengan lebih mendalam sehingga tidak muncul salah persepsi. Dalam makalah ini penulis menguraikan model pelayanan kontekstual ini dimana ada perjumpaan antara Injil dengan tradisi-tradisi Jawa Timuran yang masih dianut oleh masyarakat Desa Pulerejo kabupaten Madiun Jawa Timur. Penulis juga memaparkan model-model perjumpaan Injil dengan tradisi Jawa Timuran sebagai pola pelayanan sehingga diterima oleh masyarakat tanpa adanya sinkritisme.

\section{METODE}

Jenis penelitian yang digunakan pada penelitian ini adalah penelitian kualitatif dan bersifat penelitian etnografi. Data dalam penelitian ini dipero-

${ }^{1}$ Daniel J. Adams, Teologi Lintas Budaya (Jakarta: BPK Gunung Mulia, 2006), 49. 
leh melalui observasi partisipatif dan wawancara terarah. Data hasil wawancara dan observasi kemudian disimpulkan dan dipaparkan secara deskriptif dalam bentuk kata-kata atau tulisan. Untuk memastikan keabsahan data, penulis melakukan pemeriksaan terhadap data yang diperoleh melalui observasi dengan data yang diperoleh melalui wawancara. Istilah-istilah dalam bahasa Jawa yang muncul dalam penulisan akan diberi penjelasan agar memudahkan pembaca memahami maksud tulisan.

\section{KEBUDAYAAN MASYARAKAT JAWA}

Bagian ini membahas tentang beberapa kebudayaan masyarakat Jawa.

\section{Etika Orang Jawa}

Etika orang Jawa setidaknya memperhatikan dua hal yaitu:

\section{Kerukunan}

Kerukunan berasal dari kata "rukun" yang berarti "berada dalam keadaan selaras tanpa perselisihan dan pertentangan, bersatu dalam maksud untuk saling membantu." Keadaan rukun itu suka bekerjasama, saling menerima dalam suasana yang tenang dan sepakat. Kerukunan berarti menghilangkan tanda-tanda ketegangan dalam masyarakat sosial atau antar pribadi sehingga hubungan sosial tetap kelihatan selaras dan baik. Dalam pelayanan kontekstualisasi si pemberita hendaknya memperhatikan prinsip-prinsip kerukunan ini. Karena kerukunan atau hidup rukun merupakan suatu wujud daripada etika orang Jawa. Orang Jawa dalam hidupnya tidak ingin perselisihan dan pertentangan. Pemberitaan Injil sering menjadi pertentangan seolah-olah ada kesan bahwa dalam pemberitaan Injil itu akan menghilangkan budaya Jawa. Si pemberita hendaknya memakai prinsip kerukunan agar Injil dapat diterima dan didengar. Ia harus hati-hati tidak boleh sampai

${ }^{2}$ Petrus Oktavianus, Identitas Kebudayaan Asia dalam Terang Firman Allah (Batu Malang: YPPII, 1985), $52,53$. terjadi pertentangan dengan masyarakat dalam pemberitaan Injil. Dalam kehidupan masyarakat Jawa, kerukunan dapat diwujudkan dalam bentuk tindakan, contohnya adalah tolong menolong dalam menanggung beban (Gal. 6:2). Bertolong-tolongan dalam konsep Jawa yaitu "tulung pinulung" konsep ini sangat dipahami oleh orang Jawa. Tulung pinulung (tolong menolong) sesuatu yang dijunjung tinggi oleh orang Jawa.

\section{Sikap Tata Krama}

Dalam lingkungan masyarakat Jawa aturan atau kaidah disebut tata krama. Saliyo mengatakan "Tata berarti aturan atau kaidah dan krama berarti tingkat-tingkat bahasa dalam bahasa Jawa berarti ragam hormat" ${ }^{3}$ Dengan demikian pada mulanya tata krama ini diduga sebagai cara menghormati dengan menggunakan bahasa. Dalam perkembangannya cara menghormat itu tidak lagi hanya dengan menggunakan bahasa saja melainkan dengan berbagai cara lainnya seperti sikap, gerak, gaya, nada, irama dan tatapan. Kemudian tata krama ini diartikan sebagai adat sopan santun yang berlaku dalam masyarakat Jawa. ${ }^{4}$ Pada dasarnya tata krama itu adalah suatu cara memberi hormat kepada orang lain, muncullah tata krama keluarga, maupun tata krama bertetangga. Dalam pelayanan kontekstualisasi pun perlu menggunakan tata krama pelayanan.

Tata krama dalam menyampaikan Injil, tata krama di dalam berpakaian dalam hal menyampaikan Injil, gaya berbicara pun hendaknya ada tata kramanya, sehingga Injil dapat didengar, melalaui sikap tata krama. Hal ini merupakan pelayanan kontekstualisasi yang relevan dan tetap murni sehingga Injil tetap tersampaikan dengan baik. Tata krama ini sesuai dengan firman Tuhan, yaitu “...pakailah perkataan yang baik untuk membangun, di mana perlu supaya mereka yang mendengarnya beroleh kasih karunia." (Ef. 4:29). "Dan hendaklah kamu ramah se-

\footnotetext{
${ }^{3}$ K.S. Saliyo, "Kebudayaan dan Kesenian Domisili" Ceramah di Dinas Pariwisata, Kebumen, 1993.

${ }^{4}$ Ibid.
} 
orang terhadap yang lain, penuh kasih mesra" (Ef. 4:32). Tata krama si pemberita juga dapat diwujudkan dengan sopan santun dalam beragul (Rm. 13:13; I Tes. 4:12), sopan berdandan (I Tim. 2:9).

\section{Sikap Hidup Orang Jawa}

Uraian mengenai sikap hidup orang Jawa di dalam Serat Sasangkajati terdapat "Hasta Sila/Delapan Sikap Dasar." Hasta sila tersebut terdiri dari dua pedoman yakni Trisila dan Pancasila.

\section{Trisila}

Trisila merupakan pedoman pokok yang harus dilaksanakan setiap hari oleh manusia, dan tiga hal yang harus dituju oleh akal budi dan cipta manusia di dalam menyembah Tuhan. Trisila tersebut antara lain eling (sadar); pracaya (percaya); mituhu (setia melaksanakan perintah). Yang dimaksud eling adalah sadar untuk selalu berbakti kepada Tuhan Yang Maha Tunggal. Dimana menurut ajaran Kejawen (Pangestu) yang dimaksud dengan Tuhan yang Maha Tunggal adalah kesatuan dari tiga sifat yaitu Suksma Kawekas (Allah Ta'ala); Suksma Sejati (Rosullah); Roh Suci. Menurut ajaran ini dengan sadar terhadap Tuhan yang Maha Tunggal maka manusia akan dapat bersifat hati-hati hingga mampu memisahkan yang benar dan yang salah, yang nyata dan yang bukan dan yang berubah dengan yang tidak berubah. Sedangkan yang dimaksud dengan pracaya (percaya) ialah percaya terhadap Suksma sejati (utusannya) yang juga disebut Guru Sejati. Dan mituhu adalah setia dan selalu melaksanakan segala perintah yang disampaikan melalui utusannya. Si pemberita hendaknya memiliki sikap hidup seperti orang Jawa yaitu eling (sadar), pracaya (percaya) dan mituhu (setia). Dalam kehidupan sehari-hari dalam pergaulan dan bermasyarakat hendaknya mencerminkan ketiga sikap tersebut.

${ }^{5}$ R. Soenarto, Serat Sasongko Jati (Surakarta: Pangestu, 1968), 12.

\section{Pancasila}

Pancasila artinya watak dan tingkah laku yang terpuji, yaitu isinya rila (rela), narima (menerima nasib yang diterimanya), temen (setia pada janji), sabar (lapang dada), budi luhur (memiliki budi yang baik). ${ }^{6}$ Masyarakat desa Pulerejo adalah suatu komunitas yang masyarakatnya sangat memegang tradisitradisi Jawa Timuran walaupun jaman sudah berkembang. Misal methil, brokohan, selamatan. "Methil" atau memetik hasil panen yang pertama kali dari hasil panenan, petani di desa Pulerejo hingga hari ini masih melakukan tradisi ini sebagai bentuk ucapan syukur kepada "mbok sri" julukan dewa sri yaitu dewa padi yang telah memberikan kesejahteraan kepada para petani. Sejak tahun 1980-an orang Kristen tidak boleh melakukan upacara ini, tetapi penulis membuka kembali upacara ini sebagai model kontekstual namun gembala sidang sebagai "modhin" sebutan untuk pemuka adat, kyai dukun, orang yang dituakan untuk memimpin setiap upacara tradisi Jawa Timuran. Sementara istilah "brokohan" ada dua yaitu pada saat seseorang sudah tua usianya ia akan di-brokohi (semacam syukuran karena umur panjang) oleh keluarga, selain itu pada waktu anggota masyarakat membeli sapi atau sapinnya beranak juga dibrokohi (semacam diselamati) yang memimpin acara tradisi ini adalah modhin. Kemudian "Selamatan" banyak modelnya antara lain sunatan, kelahiran bayi, kehamilan 7 bulanan (tingkeban), pernikahan, kematian 3, 7, 40, 100, 1000 harinya yang memimpin selamatan ini juga di sebut modhin. Masyarakat desa Pulerejo sangat mendambakan kehidupan yang harmoni antar sesama baik Islam, Islam Kebatinan dengan Kristen atau sebaliknya.

Selain itu masyarakat Desa Pulerejo juga sangat menghargai toleransi. Satu prinsip hidup mereka yaitu "saya tidak mengganggu kamu, untuk itu kamu jangan mengganggu saya" ungkapan ini dalam bentuk apa pun termasuk soal-soal agama. Untuk itulah penulis memulai dengan berkontekstual de-

\footnotetext{
${ }^{6}$ Soenarto, Serat Sasongko Jati, 16.
} 
ngan kebudayaan setempat secara khusus di Desa Pulerejo. Dalam berkontekstual, tekanan utama adalah bagaimana orang Kristen dalam memberitakan Injil berkonteks dengan lingkungan hidupnya secara utuh.

Pola tersebut seperti apa yang ditekankan oleh Yakob Tomatala:

Kontekstualisasi adalah refleksi ideal dari setiap orang kristen dalam konteks hidupnya atas Injil Yesus Kristus. Yang dipentingkan di sini adalah bagaimana seharusnya Injil (yang utuh itu) ditaburkan sehingga membawa keseimbangan yang tampak dari refleksi teologi si penerima Injil (dari hakekat dirinya yang utuh-secara pribadi/ kelompok, budaya, sosial, politik, ekonomi lokal, dsb. dan keseluruhan perspektif orang-orang tersebut dalam kontesknya). Refleksi itu menampakkan pemahaman, penerimaan, pendirian, dan dampak Injil yang seimbang dalam konteks yang dimaksud menggambarkan sikap "sambutan atas Injil sebagai milik diri dan mengekspresikan pemilikan ini dalam pengertian/arti yang baru melalui bentuk budaya lokal yang dikenal yang secara fungsional melayani kebutuhan masyarakat konteks tersebut. ${ }^{7}$

Dalam bukunya Yakob Tomatala juga melanjutkan demikian:

...kontekstualisasi yang benar ditandai oleh transformasi Kristus dalam budaya. Tanpa transfor-masi akan muncul sinkritisme, dsb. Transformasi yang terjadi harus memperlihatkan keseimbangan dalam kehidupan budaya tempat Injil beroperasi. Kontekstualisasi yang benar terjadi dalam dua arah, "inkarnasi" dan "refleksi", yang dihubungkan oleh transformasi Kristus, dan ini akan membawa dampak perubahan seimbang. ${ }^{8}$

Keseimbangan dalam kehidupan budaya dimana Injil berasal dari pemberita Injil serta budaya sebagai objek misi harus dipertahankan. Injil harus tetap relevan dalam pemberitaan dimanapun dan budaya manapun.

\section{TRADISI JAWA TIMURAN DALAM MASYARAKAT DESA PULEREJO}

Ada beberapa model tradisi Jawa Timuran dalam kehidupan masyarakat desa Pulerejo yaitu:

\footnotetext{
${ }^{7}$ Yakob Tomatala, Teologi Kontekstualisasi (Malang: Gandum Mas, 2001), 2.

${ }^{8}$ Ibid, 25.
}

\section{Tradisi Methil}

Dalam masyarakat desa Pulerejo secara khusus petani ada suatu tradisi turun temurun yang harus dilakukan pada saat panen. Istilah methil ini ada dua yaitu pertama, petani mengadakan upacara methil di tempat dimana sawahnya akan dipanen. Biasanya petani ini pagi-pagi sekali sudah mempersiapkan ayam bakar, nasi, sayur, mie goreng, tahu, tempe, kemudian petani tersebut mengundang tetangga dan orang-orang yang akan memanen padi. Padi dipetik segenggam kemudian didoakan oleh modhin (kyai, dukun, orang pintar, orang yang dituakan termasuk pendeta).

Hal tersebut menunjukkan ucapan syukur kepada Dewi Sri sebagai jelmaan dewi padi. Dewi padi telah memberikan berkah dan kesejahteraan dalam pertanian. Biasanya tradisi ini dihadiri oleh 1520 orang. Setelah upacara tradisi, kemudian di doakan oleh modhin-nya, makanan dibagi-bagikan kepada semua yang hadir dan dibawa pulang, setelah selesai makan padi akan langsung dipanen. Kedua, sebelum petani melakukan panen secara keseluruhan dalam luas lahannya/sawahnya maka ia akan memotong padi segenggam kemudian dibawa pulang, pada malam harinya petani tersebut mengadakan tradisi methil, ia mengundang tetangga sebanyak 25-30 orang (sesuai dengan jumlah dan kedekatan petani dengan tetangga) tuan rumah menyediakan makanan lengkap ayam bakar, nasi, sayur tempe kering, mie goreng, tahu, rempeyek serta minuman teh hangat dan makanan kecil yang di sebut umbel (beras ketan digiling halus dibungkus dengan pisang dalamnya diisi dengan gula merah campur ampas kelapa), setelah modhin mendoakan kemudian makanan dibagibagi serta dibawa pulang (bagi petani yang mampu dalam acara tersebut menyediakan makanan tambahan). Setelah modhin mendoakan, ia akan mendapatkan binat sebagai ucapan terima kasih dari tuan rumah yang telah didoakan. "binat" adalah bentuk atau wujud dari ucapan terima kasih yang diberikan kepada modhin dari tuan rumah yang menyelenggarakan tradisi-tradisi Jawa Timuran berbentuk uang, 
penerimaannya bervariasi Rp5000 sampai lebih dari Rp20.000 tergantung kemampuan dari petani.

\section{Tradisi Brokohan}

Maksud dari tradisi brokohan ini adalah mengucapkan syukur kepada Tuhan atas kebaikan Tuhan. Ada dua jenis brokohan menurut tradisi masyarakat desa Pulerejo: Pertama, brokohan untuk orang yang sudah lanjut usia, keluarganya mengadakan acara ini sebagai rasa syukur kepada Tuhan bahwa Tuhan baik, memelihara sampai di usia tua bahkan masih bisa menikmati makanan dengan baik (semakin brokoh). Dalam tradisi ini tuan rumah menyediakan sedikit makanan sederhana tuan rumah mengundang tetangga kiri dan kanannya saja. Pemimpin acara ini juga modhin akan tetapi bukan suatu keharusan, pemimpin acara biasa juga ketua RT/RW atau yang paling tua yang hadir dalam acara tersebut. Kedua, brokohan atas pembelian seekor sapi atau sapinya beranak, dengan tujuan supaya Tuhan memelihara ternaknya dijauhkan dari marabahaya. Acaranya sama dengan brokohan untuk orang tua hanya saja doanya sedikit berbeda.

\section{Selamatan (Wilujengan)}

Koentjaraningrat menjelaskan maksud selamatan oleh dalam bukunya Kebudayaan Jawa sebagai berikut:

....hanyalah untuk memelihara rasa solidaritas sosial dan untuk menciptakan suasana atau rasa damai, bebas dari rasa permusuhan dan prasangka terhadap orang lain... suatu perayaan atas peristiwa yang penuh kebahagiaan. ${ }^{9}$

Selamatan ini jenisnya adalah pindah rumah, pada waktu memasuki rumah baru, pada waktu mengganti nama, sebelum melakukan perjalanan jauh, pada waktu merayakan kenaikan pangkat, pemindahan tugas dan pekerjaan.

\footnotetext{
${ }^{9}$ Koentjaraningrat, Kebudayaan Jawa (Jakarta: PN Balai Pustaka, 1984), 347.
}

\section{PERJUMPAAN INJIL DENGAN TRADISI JAWA TIMURAN DI DESA PULEREJO}

Sebagai landasan Alkitabiah dalam makalah ini adalah:

Firman itu telah menjadi manusia, dan diam diantara kita, dan kita telah melihat kemuliaan-Nya, yaitu kemuliaan yang diberikan kepada-Nya sebagai Anak Tunggal Bapa, penuh kasih karunia dan kebenaran... Tidak seorang pun yang pernah melihat Allah; tetapi Anak Tunggal Allah, yang ada dipangkuan Bapa, Dialah yang menyatakan-Nya. (Yoh. 1:14,18).

Yesus Kristus adalah pernyataan Allah yang utuh dalam budaya manusia dan dalam pengejawantahan Allah di dalam Yesus Kristus, manusia dapat melihat Allah. Seperti yang ditekankan oleh Tomatala dalam bukunya sebagai berikut:

Logos menjadi manusia mempunyai implikasi yang luas. Ini berarti lahir ke dunia sebagai manusia, hidup dalam sejarah manusia, menjadi bagian dalam konteks budaya manusia, dst... singkatnya, berpadu dengan hakekat manusia secara utuh. Dengan demikian, inkarnasi melambangkan solidaritas Yesus Kristus dengan manusia secara utuh dalam lingkup sosial budaya manusia. Namun, perlu disadari bahwa inkarnasi Kristus terjadi bukan untuk tujuan inkarnasi itu sendiri, melainkan untuk menyatakan Allah kepada dunia (Yoh. 1:18). Perlu ditegaskan bahwa inkarnasi Kristus memiliki tujuan misional untuk membuktikan kasih Allah kepada dunia (Yoh. 3:16), bagi pembebasan dunia itu sendiri (Yoh. 1:29)... Untuk itu, kita melihat bahwa Sang Logos secara total berpadu dengan budaya dalam konteks sejarah, mengenal dan dikenal dalam bentuk, arti, dan fungsi setiap elemen budaya, dan dalam posisiNya inilah Ia menyatakan Allah kepada dunia.... Kristus, dalam inkarnasi-Nya mengambil seluruh aspek budaya manusia dan menggunakannya sebagai wahana misi, menyatakan kehendak Allah yang kekal kepada dunia melalui konteks budaya di mana Ia ada. ${ }^{10}$

Budaya manusia merupakan budaya yang nyata, yang dapat dikenal asal-usul, keluarga dan kegiatankegiatannya. Demikian juga Yesus Krsitus dalam inkarnasinya Ia menjadi bagian dalam budaya seutuhnya. Ia di kenal sebagai orang Galilea (Luk. 23: 5-7), berasal dari Nazareth (Mat. 2:22, 23; Luk. 18: 37), orang mengenal Yesus dan keluarga-Nya (Mat. 13:

\footnotetext{
${ }^{10}$ Tomatala, Teologi Kontekstualisasi, 22-23.
} 
55-56; Mrk. 6:1,3; Luk. 4:16) Ia melakukan misi (Yoh. 4:34). Ia datang untuk melayani (Mrk. 10:45; Luk. 18:31-34).

Prinsip-prinsip dalam penerapannya yaitu: (1) Injil yang satu akan selalu beroperasi lintas budaya yang diekspresikan dalam Alkitab dengan terminologi budaya; (2) Sasaran Injil yang satu adalah manusia yang multidimensi sebagai makhluk rohani, budaya, sosial, dan makhluk ekonomi. Sama halnya dengan Injil yang membebaskan secara utuh, maka pelayanan Injil pun harus dilaksanakan secara utuh menjawab seluruh kehidupan manusia dalam segala aspek, secara prioritas dan berimbang. Selain itu, dalam perjumpaan antara Injil dan tradisi Jawa Timuran yang perlu diperhatikan adalah sebagai berikut: (1) Meniadakan hal-hal yang bernuansa sinkritis seperti pemakaian kata "mbah, danyang", dan sebagainya; (2) Mengubah maknanya, tujuannya semula kepada arwah-arwah nenek moyang, alam semesta, benda, pohon, diubah menjadi ditujukan kepada Tuhan; (3) Memakai sarana-sarana dalam budaya mereka misalnya: pakaian, rasa hormat kepada yang lebih tua, menghargai makanan yang disediakan; (4) Dijadikan arti baru, simbol-simbol yang terdapat dalam acara tradisi serta makanan mereka mengungkapkan kepada Tuhan Yesus Kristus. Proses kontekstualisasi di GKII Pulerejo selama 10 tahun de-

\section{DAFTAR RUJUKAN}

Adams, Daniel J. Teologi Lintas Budaya. Jakarta: BPK Gunung Mulia, 2006.

Koentjaraningrat. Kebudayaan Jawa. Jakarta: PN Balai Pustaka, 1984.

Saliyo, KS. "Kebudayaan dan Kesenian Domisili" Ceramah Dinas Pariwisata Kebumen, 1993. ngan tradisi masyarakat, direspon yang sangat baik dari jemaat maupun masyarakat. Transformasi kehidupan pun sangat respek. Pemuka adat, pemuka agama dan pejabat desa dapat bergandengan tangan dengan gereja, hamba Tuhan. Tatkala ada perayaan-perayaan Kristen mereka datang dan mendengarkan berita kesukaan Injil diwartakan, mereka mendengar bahwa Yesus Kristus adalah Juruselamat mereka.

\section{KESIMPULAN}

Pemberitaan Injil yang kontekstual harus disikapi dengan bijak, tanpa ada intoleransi dalam masyarakat. Identitas sebagai orang Kristen harus jelas, menghargai budaya tanpa adanya sinkritisme. Menghargai budaya tidak selalu sinkritisme ketika makna diubah. Dalam perjumpaan antara Injil dan tradisi Jawa Timuran yang perlu diperhatikan adalah: (1) Meniadakan hal-hal yang berbau sinkritisme; (2) Mengubah maknanya, tujuannya semula kepada arwah-arwah nenek moyang, alam semesta, benda, pohon, diubah menjadi ditujukan kepada Tuhan; (3) Memakai sarana-sarana dalam budaya mereka; (4) Dijadikan arti baru, simbol-simbol yang terdapat dalam acara tradisi serta makanan mereka mengungkapkan kepada Tuhan Yesus Kristus.

Oktavianus, Petrus. Identitas Kebudayaan Asia dalam Terang Firman Allah. Batu Malang: YPPII, 1985.

Soenarto, R. Serat Sasongko Jati. Surakarta: Pangestu, 1968.

Tomatala, Yakob. Teologi Kontekstualisasi. Malang: Gandum Mas, 2001. 